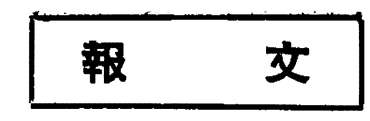

\title{
輕症脚氣患者の臨床統計 \\ Statistical of the Beriberi Casess in Out Patient Clinic
}

\author{
柳全太 郎 \\ (Kintaro Yanagi)
}

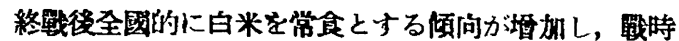
中铪んぞその影を絕つたといつても良い程の脚氣か洅び 坦加の顺向を巡りつつあることは，余か凬に指摘したと

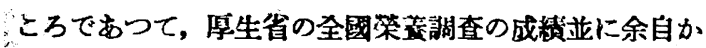
らの行つた㭠計に基ついてこれを馆登して昨年の祭获食 程學會總會に㧊いて發表したところである。然るに日本 人の主食たる米はそれを白米として擗取することか國民 の殆んど決定的な要求であり，一方に抗いて米の㟫精技

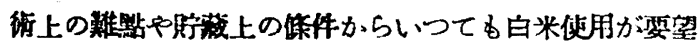

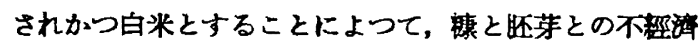
なる徒暂が救われて，油料算源，家音の蛋白資源などと

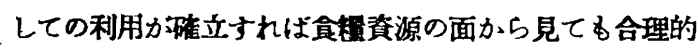
である等の諸條件か附道するので，白米常倉を國民今後 の食形式として悪めさるを得ない現狀となつている。然

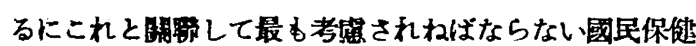
上の重要問題は榞質消掏量と不可分なるビタミン $\mathrm{B}_{1}$ の 補充問題である。ビタミン $\mathrm{B}_{1}$ が白米を主会とする日本 人に果して充分であるか不足するかは重要なる問題であ つて, 若し触乏の度か保健上不問に附し得ない、程度であ ればそれを如何にして補充するかが关の重要なる課題 となるわけである。

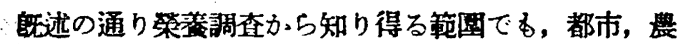
村を通して約 1 割程度の滕盖腱反射消失の症狀を视如得 る所であり，しかるそれか逐年剒加の傾向を示している

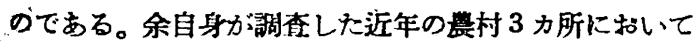

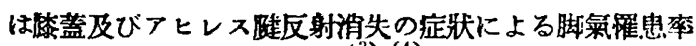

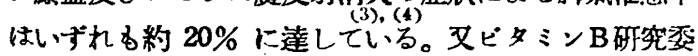
員會に打いては多数の碎究者の棕合的意見として，現在 の日本人には活恬中等度以上のビタミン $\mathrm{B}_{1}$ 缺乏がある と㒋定している。
余はこの楚の瓷料を㘿加する一助として，本年 8 月中

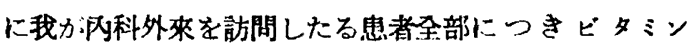
$\mathrm{B}_{1}$ 缺乏に萑つく症桀が何の程度の频度汇認め得るかを

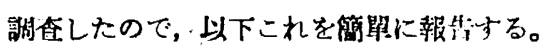

(調查人虽並に調查方法)

昭和 26 年 8 月 1 日より 9 月 5 日下至る外來浐察日約

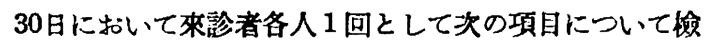

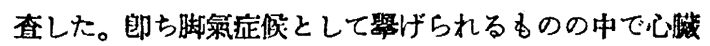
所見，食態障碍，便秘，隐总感等は他の疾思に基因する

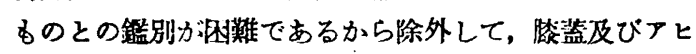

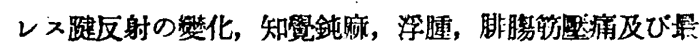
小血熙の低下の 6 項目をいわゆる签症脚氣の症狀從つて ビタミン $B_{1}$ の觔之症獎として探用し，各㭧者につき享 ら症候本位の檢查を行い，診断は後にこれら症候的の 2 個以上を有する者を脚氣として計上したのである。勿論

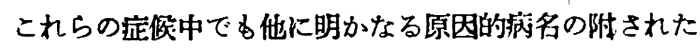

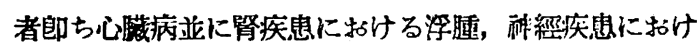
る知琵鈍麻等は除外したのである。

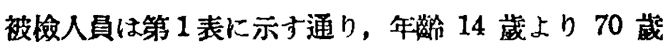
以上R及ぶ男女合計 375 名で男女汪汪同整を占めでり その中過本数は20 40 歲間の成人であつた。(第 1 表)

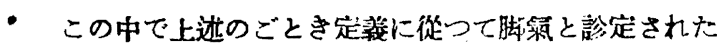
者は，男 186 名中 40 名 (21.5\%)，女 189 名中 69 名 (36. 5\%) であつて女に多人, 合部 109 名 (29.0\%)である。

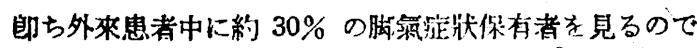
ある。その所有症候の頻度を見ると第 2 表のでとくであ

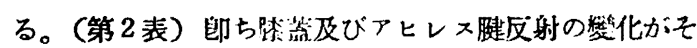

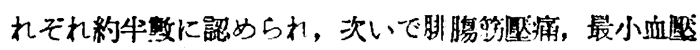

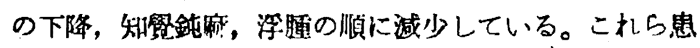
者の独業關係を見ると第3表のごとくであうて，男では

第 1 表 內科外来患者门年䀫分布

\begin{tabular}{|c|c|c|c|c|c|c|c|c|}
\hline 年 踣 & $14 \sim 19$ & $20 \sim 29$ & $30 \sim 39$ & $40 \sim 49$ & $50 \sim 59$ & $60 \sim 69$ & 70 以上 & 合 㝘 \\
\hline 男 & 20 & 90 & 30 & 14 & 16 & 15 & 1 & 186 \\
\hline 女 & 20 & 90 & 35 & 19 & 19 & 5 & 1 & 189 \\
\hline 合 計 & 40 & 180 & 65 & 33 & 35 & 20 & 1 & 375 \\
\hline
\end{tabular}




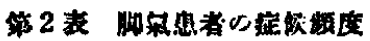

\begin{tabular}{|c|c|c|}
\hline 鿊筷 & 早 & k \\
\hline 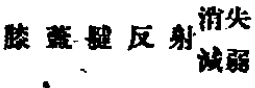 & $\begin{array}{l}20.0 \\
27.5\end{array} 47.5 \%$ & $\begin{array}{l}17.4 \backslash 52.2 \% \\
34.8\end{array}$ \\
\hline テヒレス国反射消失 & $\begin{array}{l}15.9 \\
17.5\end{array} 32.5 \%$ & $\begin{array}{l}11.6 \\
40.6\end{array} 52.2 \%$ \\
\hline  & $45.0 \%$ & $30.4 \%$ \\
\hline 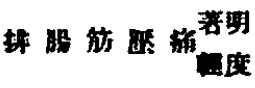 & $\begin{array}{l}30.0 \\
12.5\end{array} 42.5 \%$ & $\begin{array}{l}31.9>47.8 \% \\
15.9\end{array}$ \\
\hline 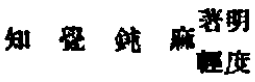 & $\begin{aligned} 15.0 \\
2.5\end{aligned} 17.5 \%$ & $\begin{aligned} 23.2 & \\
8.7 & \end{aligned} 31.9 \%$ \\
\hline 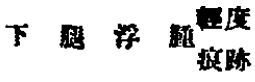 & $\begin{array}{l}5.0 \\
7.5 \\
12.5 \%\end{array}$ & $\begin{array}{l}4.3 \\
8.7\end{array} 13.0 \%$ \\
\hline
\end{tabular}

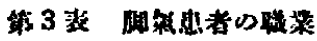
朝分有

\begin{tabular}{|c|c|c|c|c|}
\hline \multicolumn{2}{|c|}{ 筫 } & \multicolumn{2}{|c|}{ 女 } & 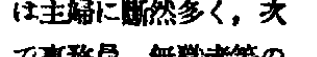 \\
\hline 赫箱自 & 11 & 主 姑 & 25 & 㒋となつて屈る。（第 \\
\hline คิㄱำ & 6 & 来础员 & 17 & 3表) \\
\hline 慗 & 6 & 然 㢺 & 16 & 更に全被姶者につ、 \\
\hline 祭 生 & 4 & 女 中 & 3 & 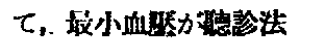 \\
\hline 㣮人 & 2 & 客 & 2 & の第 4 鸬で $60 \mathrm{~mm} \mathrm{Hg}$ \\
\hline 外卒真 & 2 & 数 & 1 & 以下となつている者を \\
\hline 工 & 1 & 弮容的 & 1 & 下降者として取り，又 \\
\hline 史 圆 & 1 & 時研工 & 1 & 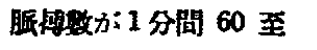 \\
\hline 棑 瓷 & 1 & 崔 娪 & 1 & 以下となつている者を \\
\hline 跤本藮 & 1 & 悬 莱 & 1 & 徐显として取つて見る \\
\hline 渱專手 & 1 & 霍 子 & 1 & と筙 4 表の示す通りで \\
\hline 印既工 & 1 & & & ある。(第 4 表)この・ \\
\hline 﨤 迹 & 1 & V & & 数佂は全部がピタミン \\
\hline 酒起菜 & 1 & - & & $\mathrm{B}_{1}$ 缺乏に基づくのの \\
\hline 毁租的 & 1 & & & とは盶じ雔いが，その \\
\hline 合䗑 & 40 & 合鼓 & 69 & 主受原因としては既容 \\
\hline
\end{tabular}

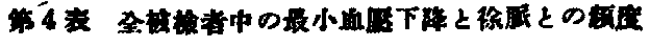

\begin{tabular}{|c|c|c|}
\hline 项 日 任 江 & 男 & 女 \\
\hline 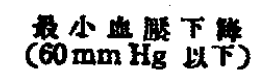 & $\frac{39}{186}=21.0 \%$ & $\frac{38}{189}=20.1 \%$ \\
\hline 徐 $60 / \mathrm{min}$ 以下 $)^{\text {. }}$. & $\frac{14}{186}=7.5 \%$ & $\frac{8}{189}=4.7 \%$ \\
\hline
\end{tabular}



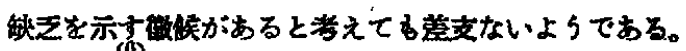

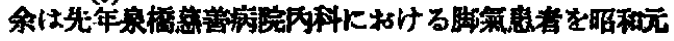
年から 10 年にわたつて策新したことがあるが，年々䄪

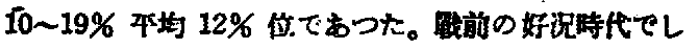

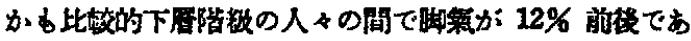
つたことを見れば，今日の余の成模たる $30 \%$ け明が 音本であると見て良いところで，一般家突の徤康人では



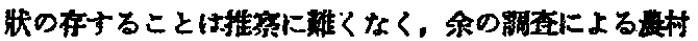

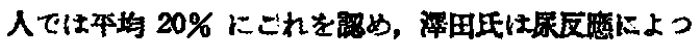

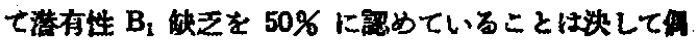
然ではないと倨ずる。

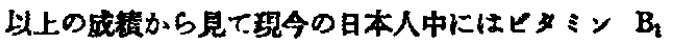

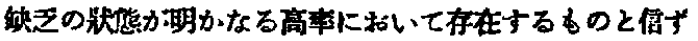
る。

\section{艾献}

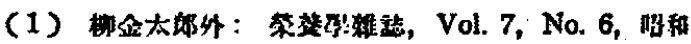
24 年 11 月.

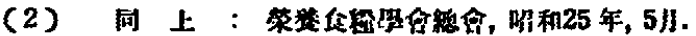


和 25 年 1 3 $\mathrm{H}$.

(4) 间上：同上, Vol. \&, No. 2. 倨和 26 年 3 月.

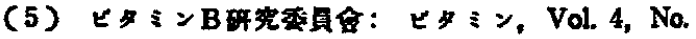
4, 昭和 26 年 9 月.

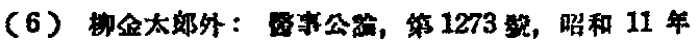
12 月.

\section{各種カルシシム監の生體內吸收利用に關する研究}

Studies on the utilization and absorption of various calcium salts in the body

\section{古武門 三 (Ynzo Kotalro)}



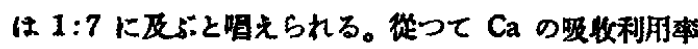

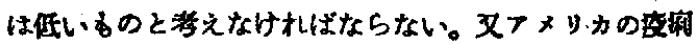



